\title{
Penerapan Menu Engineering dalam Penetapan Profitabilitas Menu A'la Carte
}

\section{Aisyah Fadhilla Ramadhani1*, Lise Asnur2}

1,2 Universitas Negeri Padang, Padang, Indonesia

\section{A R T I C L E I N F O \\ Article history: \\ Received May 22, 2021 \\ Revised May 29, 2021 \\ Accepted August 14, 2021 \\ Available online October 25, 2021 \\ Kata Kunci: \\ A'la Carte, Menu Engineering, \\ Profitabilitas \\ Keywords: \\ A'la Carte, Engineering Menu, Profitability

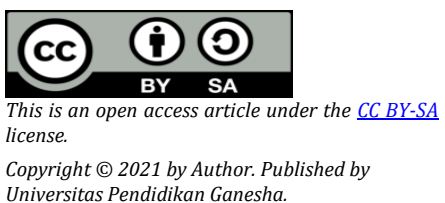

\begin{abstract}
A B S T R A K
Pada masa pandemi covid-19 seperti saat ini perkembangan dunia pariwisata Indonesia mengalami penurunan kunjungan yang sangat signifikan. Tujuan umum penelitian ini adalah untuk menganalisis Menu A'la Carte yang ada di Mentawai Restaurant Pangeran Beach Hotel Padang melalui metode menu engineering, dengan menggunakan metode ini dapat diketahui tingkat profitabilitas menu di Mentawai restaurant. Adanya penelitian ini diharapkan pihak hotel dapat melakukan evaluasi dan peningkatan dalam membuat kreasi menu makananan yang menarik konsumen, agar pendapatan Pangeran Beach Hotel Padang pada bagian food and beverage di Mentawai restaurant meningkat. Jenis penelitian yang digunakan adalah deskriptif kuantitatif. Deskriptif digunakan untuk mengetahui keberadaan variabel mandiri. Data dianalisis pada penelitian ini adalah tingkat profitabilitas Menu A'la Carte di Mentawai restaurant. Analisis data penelitian ini menggunakan teknik menu engineering worksheet pada microsoft excel. Hasil penelitian ini menunjukan bahwa menu A'la Carte (Oktober - Desember 2020) dan (Januari-Maret 2021) yang memiliki profitabilitas yang tinggi sebanyak 25 menu.
\end{abstract}

\section{A B S T R A C T}

During the COVID-19 pandemic, as currently, the development of the Indonesian tourism world experienced a very significant decline in visits. The general purpose of this study is to analyze the A'la Carte Menu in the Mentawai Restaurant Pangeran Beach Hotel Padang through the menu engineering method, using this method the level of profitability of the menu at the Mentawai restaurant can be known. With this research, it is hoped that the hotel can evaluate and improve in making food menu creations that attract consumers, so that the income of Prince Beach Hotel Padang in the food and beverage section at the Mentawai restaurant increases. The type of research used is descriptive quantitative. Descriptive is used to determine the existence of independent variables. The data analyzed in this study is the level of profitability of the A'la Carte Menu at the Mentawai restaurant. Analysis of the research data using the engineering worksheet menu technique in Microsoft Excel. The results of this study show that the A'la Carte menus (October-December 2020) and (January-March 2021) which have high profitability are 25 menus.

\section{PENDAHULUAN}

Pada masa pandemi Covid-19 seperti saat ini perkembangan dunia pariwisata Indonesia mengalami penurunan kunjungan yang sangat signifikan (Nasution et al., 2020; Paramita \& Putra, 2020). Hal tersebut dapat dilihat dari jumlah kunjungan wisatawan mancanegara (wisman) ke Indonesia pada Desember 2020 yakni sebanyak 164.088 ribu kunjungan dan mengalami penurunan sebesar -88,08\% dibandingkan bulan Desember 2019 yang berjumlah 1.377.067 kunjungan (Djausal et al., 2020; Utami \& Kafabih, 2021). Pariwisata menjadi salah satu sektor yang mendatangkan penghasilan terbanyak di Indonesia. Pariwisata pada umumnya diartikan sebagai perjalanan yang biasa dilakukan sendiri maupun kelompok menuju suatu tempat untuk mendapatkan kepuasan (Ferdiansyah et al., 2020; Kanom et al., 2020). Salah satu Provinsi di Indonesia yang memiliki banyak destinasi wisata adalah Provinsi Sumatera Barat. Provinsi Sumatera Barat terkenal dengan keindahan alam dan beragam budaya yang jarang ditemui di daerah lain. Dilihat dari sektor pariwisata, beberapa daerah yang ada pada provinsi Sumatera Barat memiliki destinasi wisata dengan nilai kearifan lokal yang sangat tinggi tidak terkecuali ibu kota Provinsi Sumatera Barat yaitu Kota Padang (Hesna et al., 2017; Masful, 2017). Kota Padang memiliki potensi dan daya tarik yang cukup kuat, baik untuk perjalanan bisnis, ataupun wisata. Sumatra Barat terkenal akan wisata pulau-pulau yang cantik serta wisata pantai yang indah (Besra, 2015; Dewilda et al., 2019). Salah satu hotel yang terkenal di kota Padang yakni Pangeran Beach Hotel Padang yang merupakan salah satu hotel bintang empat di Kota Padang. Hotel ini terletak di Jalan Ir Juanda No. 79 dan didirikan pada tanggal 21 Desember 1989. Hotel Pangeran Beach merupakan hotel kedua dari tiga hotel yang dibangun oleh Bapak Sy.Dt.Pangeran. Perusahaan ini merupakan usaha swasta nasional pribumi dengan bentuk badan hukum Perseroan Terbatas (PT) "PT Istano Pangeran”. Pada tahun 2018 total kamar yang beroperasi berjumlah 
181 kamar dan terbagi dari 6 tipe kamar dan memiliki fasilitas penunjang seperti, Kolam renang, fitness, lounge bar, restoran serta fasilitas penunjang lainnya. Pangeran Beach Hotel memiliki beberapa departemen yaitu departemen Front Office, Housekeeping, Sales Marketing, Engineering, HRD, Accounting dan Food and beverage. Food and beverage merupakan salah satu departemen yang ada di hotel yang sangat berperan dalam pendapatan hotel. Food and beverage terbagi dua yaitu product dan service.

Mentawai Restaurant merupakan bagian yang tergabung dalam Food and Beverage Department di Pangeran Beach Hotel Padang. Mentawai Restaurant merupakan restoran hotel yang menyediakan jasa penjualan makanan dan minuman untuk para tamu yang menginap di hotel dan juga bagi tamu dari luar yang tidak menginap di hotel. Mentawai Restaurant berada di dekat swimming pool area dan memiliki konsep indoor dan outdoor. Restoran ini menyediakan hidangan A'La Carte dan Buffet. Mentawai restaurant memiliki menu A'la Carte dengan 9 kategori yang menarik yang ditawarkan kepada tamu yang menginap di Pangeran Beach Hotel Padang. Menu yang ditawarkan mulai dari menu dengan kategori Any Kind of Soup, Sandwiches, Snack, Pasta and Pizza, Salad, Western Favorites, Burger, Asian Dishes, dan Juice Selection. Menu menjadi salah satu bagian dari keseluruhan penampilan restoran, selain itu menu juga memiliki nilai sebagai alat untuk membantu menjual seluruh makanan dan minuman yang disediakan oleh restoran. Peningkatan penjualan melalui menu merupakan suatu bentuk profitabilitas. Profitabilitas pada dasarnya merupakan suatu bentuk kemampuan perusahaan untuk mendapatkan keuntungan dengan memanfaatkan sumber daya yang dimiliki perusahaan seperti aktiva, modal atau penjualan perusahaan (Bhawa \& Dewi S., 2015; Rahmah \& Komariah, 2016). Tingkat profitabilitas dilakukan untuk mengukur tingkat efektivitas pengelolaan terhadap penjualan menu-menu yang ditawarkan (Suherman et al., 2019). Perhitungan profitabilitas ini dilakukan dengan metode menu engineering. Menu engineering diartikan sebagai serangkaian proses yang dilakukan manajemen dalam evaluasi untuk penyusunan harga, desain dan isi menu pada saat sekarang maupun yang akan datang. Hanya saja kenyataan dilapangan menunjukkan bahwa terdapat beberapa permasalahan yang ditemui pada bagian kitchen. Permasalahan yang ditemui terkait dengan menu yaitu, terdapatnya beberapa menu a'la carte di Mentawai restaurant yang memiliki profit tinggi tetapi kurang diminati konsumen. Terdapat juga menu-menu yang kurang populer tetapi memiliki banyak stock persedian. Cost pada menu-menu yang kurang populer juga tinggi seperti seperti buntut, seafood, dan beef. Adanya pandemic covid-19 kemudian berdampak pada tingkat profitabilitas menu $a^{\prime} l a$ carte yang ada menjadi tidak stabil karena penurunan jumlah penjualan.

Beberapa penelitian yang telah dilakukan sebelumnya mengungkapkan bahwa menu ala carte memiliki empat klasifikasi yakni scilicet 8 Star, 5 Ploughhorse, 4 Puzzle, dan 2 Dog, sehingga data kinerja yang lebih rinci telah disediakan mengenai item menu yang berarti bahwa hasil analisis dapat disajikan baik untuk tujuan bisnis jangka pendek maupun jangka Panjang (Juliana et al., 2021). Hasil penelitian selanjutnya juga mengungkapkan bahwa menu parsial dan penjualan sugestif berpengaruh signifikan terhadap keputusan pembelian, sehingga perusahaan harus mengevaluasi dan meningkatkan kedua variabel ke dalam perencanaan perusahaan untuk meningkatkan keputusan pembelian pada menu a'la carte di Grand Pasundan Convention Hotel (Oktaviani et al., 2018). Penelitian lainnya juga mengungkapkan bahwa teknik rekayasa menu atau menu engineering terbukti berhasil memberikan data identifikasi performa setiap menu yang disajikan dari berbagai aspek mulai dari tingkat popularitas menu makanan di mata konsumen sampai tingkat kontribusi keuntungan yang diberikan oleh setiap menu yang ada (Tumpuan, 2021). Berdasarkan beberapa hasil penelitian tersebut dapat dikatakan bahwa sistem penerapan menu engineering dapat membantu pihak restoran untuk mengidentifikan performa menu yang disajikan, sehingga dapat meningkatkan jumlah penjualan. Hanya saja pada penelitian sebelumnya belum terdapat kajian mengenai penerapan menu engineering dalam penetapan profitabilitas menu a'la carte di Mentawai Restaurant Pangeran Beach Hotel Padang. Sehingga penelitian ini difokuskan pada kajian tersebut dengan tujuan untuk mengidentifikasi posisi menu a'la carte yang ada di Mentawai restaurant Pangeran Beach Hotel.

\section{METODE}

Penelitian ini menggunakan jenis penelitian deskriptif dengan pendekatan kuantitatif. Penelitian deskriptif dilakukan dengan tujuan untuk mengetahui keberadaan variable mandiri, baik hanya pada satu variabel atau lebih (variabel yang berdiri sendiri atau variabel bebas) tanpa membuat perbandingan variabel itu sendiri dan mencari hubungan dengan variabel lain. Penelitian ini menggunakan data sekunder, dengan subjek penelitian yakni pegawai Mentawai restaurant. Pengumpulan data dalam penelitian dilakukan dengan menggunakan studi dokumtasi untuk mengetahui tingkat profitabilitas menu di Mentawai restaurant Pangeran Beach Hotel Padang. Analisis data hasil penelitian dilakukan dengan menggunakan analisis metode menu engineering worksheet pada microsoft excel. Analisis diawali dengan melakukan pengemlompokan menu yang memiliki tingkat profitabilitas tinggi dan tingkat profitabilitas 
rendah dengan menggunakan rumus contribution margin. Margin kontribusi untuk setiap jenis makanan dan minuman dihitung dengan cara harga jual dikurangi dengan harga pokok tersebut. Setelah menghitung contribution margin setiap menu makanan dan minuman, selanjutnya merangkum total margin kontribusi menu (Total CM). Hasil dari margin kontribusi setiap menu dikalikan dengan masing-masing menu mix yang menghasilkan total margin kontribusi. Selanjutnya setelah selesai melakukan perhitungan persentase margin kontribusi setiap makanan dan minuman. Setiap margin kontribusi dari masing-masing menu dibagi dengan total margin kontribusi menu tersebut kemudian dikalikan $100 \%$. Setelah nilai dari persentase margin kontribusi dari masing-masing menu item didapatkan analisis dilanjutkan dengan menghitung contribution margin category yang dikategorikan menjadi tinggi atau rendah. Hasil perhitungan tersebut dapat berupa: nilai $\mathrm{CM} \%$ = nilai $\mathrm{CM}$ maka profitabilitas rendah, nilai $\mathrm{CM} \%>$ nilai $\mathrm{CM}$ maka profitabilitas tinggi, atau nilai $\mathrm{CM} \%<$ nilai CM maka profitabilitas rendah.

\section{HASIL DAN PEMBAHASAN}

Hasil

Hasil penelitian mengenai tingkat profitabilitas menu A'la Carte dengan Kategori Any Kind of Soup di Mentawai Restaurant Pangeran Beach Hotel Padang dengan menggunakan metode menu engineering pada bulan Oktober-Desember 2020 dan Januari - Maret 2021 yang telah dihitung menggunakan menu engineering worksheet dengan bantuan microsoft excel dapat dilihat pada Tabel 1.

Tabel 1. Menu Engineering Worksheet Menu A'la Carte kategori Any Kind of Soup

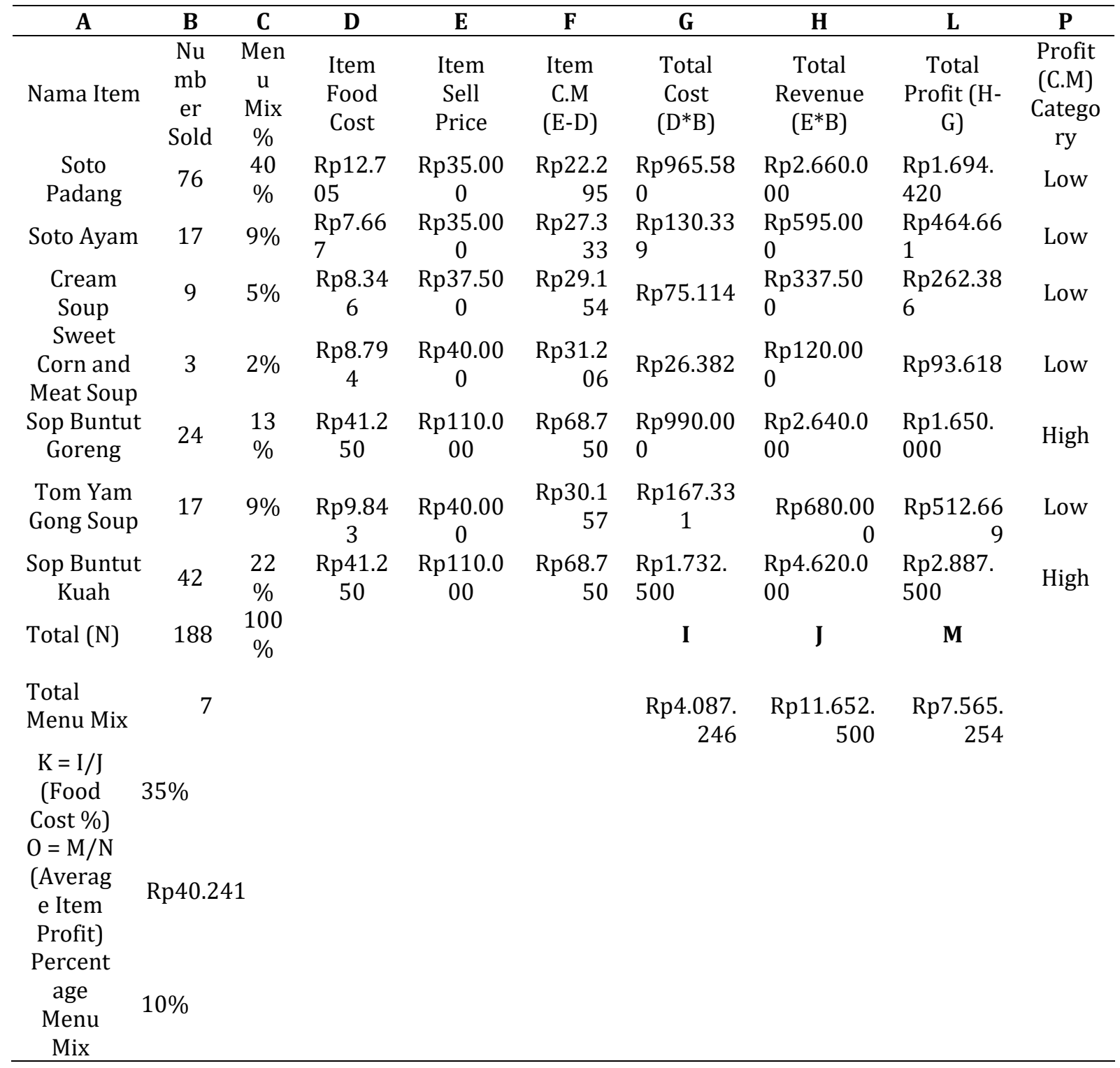


Berdasarkan tabel 1 dapat dilihat bahwa hasil analisis dari 7 menu di kategori Any Kind of Soup yang memiliki profitabilitas tinggi adalah Sop Buntut Goreng dan Sop Buntut Kuah. Selanjutnya analisis dilakukan terhadap tingkat profitabilitas menu A'la Carte dengan Kategori Sandwich di Mentawai Restaurant Pangeran Beach Hotel Padang dengan menggunakan metode menu engineering pada bulan Oktober-Desember 2020 dan Januari - Maret 2021. Adapun hasil analisis data disajikan pada Tabel 2.

Tabel 2. Menu Engineering Worksheet Menu A'la Carte kategori Sandwich

\begin{tabular}{|c|c|c|c|c|c|c|c|c|c|}
\hline $\mathbf{A}$ & B & C & D & $\mathbf{E}$ & $\mathbf{F}$ & G & $\mathbf{H}$ & $\mathbf{L}$ & $\mathbf{P}$ \\
\hline $\begin{array}{l}\text { Nama } \\
\text { Item }\end{array}$ & $\begin{array}{c}\text { Numb } \\
\text { er } \\
\text { Sold }\end{array}$ & $\begin{array}{c}\text { Men } \\
\text { u } \\
\text { Mix } \\
\%\end{array}$ & $\begin{array}{l}\text { Item } \\
\text { Food } \\
\text { Cost }\end{array}$ & $\begin{array}{l}\text { Item } \\
\text { Sell } \\
\text { Price }\end{array}$ & $\begin{array}{c}\text { Item } \\
\text { C.M } \\
\text { (E-D) }\end{array}$ & $\begin{array}{l}\text { Total } \\
\text { Cost } \\
\left(D^{*} B\right)\end{array}$ & $\begin{array}{c}\text { Total } \\
\text { Revenue } \\
\left(\mathrm{E}^{*} \mathrm{~B}\right)\end{array}$ & $\begin{array}{l}\text { Total } \\
\text { Profit } \\
(\mathrm{H}-\mathrm{G})\end{array}$ & $\begin{array}{c}\text { Profit } \\
\text { (C.M) } \\
\text { Catego } \\
\text { ry }\end{array}$ \\
\hline $\begin{array}{c}\text { Triple } \\
\text { Decker } \\
\text { Sandwic } \\
\text { h }\end{array}$ & 3 & $30 \%$ & $\begin{array}{c}\text { Rp21.7 } \\
88\end{array}$ & $\begin{array}{c}\text { Rp75.0 } \\
00\end{array}$ & $\begin{array}{c}\text { Rp53.2 } \\
12\end{array}$ & $\begin{array}{c}\text { Rp65.36 } \\
4\end{array}$ & $\begin{array}{c}\mathrm{Rp} 225.0 \\
00\end{array}$ & $\begin{array}{c}\text { Rp159.6 } \\
36\end{array}$ & Low \\
\hline $\begin{array}{c}\text { Chicken } \\
\text { Sandwic } \\
\text { h } \\
\text { Egg }\end{array}$ & 5 & $\begin{array}{c}167 \\
\%\end{array}$ & $\begin{array}{c}\text { Rp14.6 } \\
45\end{array}$ & $\begin{array}{c}\mathrm{Rp} 75.0 \\
00\end{array}$ & $\begin{array}{c}\text { Rp60.3 } \\
55\end{array}$ & $\begin{array}{c}\text { Rp73.22 } \\
5\end{array}$ & $\begin{array}{c}\text { Rp375.0 } \\
00\end{array}$ & $\begin{array}{c}\text { Rp301.7 } \\
75\end{array}$ & High \\
\hline $\begin{array}{c}\text { Sandwic } \\
\mathrm{h}\end{array}$ & 2 & $0 \%$ & $\begin{array}{c}\text { Rp11.8 } \\
95\end{array}$ & $\begin{array}{c}\text { Rp65.0 } \\
00\end{array}$ & $\begin{array}{c}\text { Rp53.1 } \\
05\end{array}$ & Rp- & $\begin{array}{c}\mathrm{Rp} 130.0 \\
00\end{array}$ & $\begin{array}{c}\text { Rp130.0 } \\
00\end{array}$ & Low \\
\hline Total (N) & 10 & $\begin{array}{c}197 \\
\%\end{array}$ & & & & I & $\mathrm{J}$ & M & \\
\hline $\begin{array}{c}\text { Total } \\
\text { Menu } \\
\text { Mix }\end{array}$ & 3 & & & & & $\begin{array}{c}\text { Rp138.5 } \\
89\end{array}$ & $\begin{array}{c}\text { Rp730.0 } \\
00\end{array}$ & $\begin{array}{c}\text { Rp591.4 } \\
11\end{array}$ & \\
\hline $\begin{array}{l}\mathrm{K}=\mathrm{I} / \mathrm{J} \\
\text { (Food } \\
\text { Cost \%) } \\
\mathrm{O}=\mathrm{M} / \mathrm{N} \\
\text { (Average } \\
\text { Item } \\
\text { Profit) } \\
\text { Percenta } \\
\text { ge Menu } \\
\text { Mix }\end{array}$ & Rp59.14 & & & & & & & & \\
\hline
\end{tabular}

Berdasarkan Tabel 2 diatas dapat dilihat bahwa hasil analisis dari 3 menu di kategori Sandwiches yang memiliki profitabilitas tinggi adalah Chicken Sandwich. Selanjutnya analisis dilakukan terhadap tingkat profitabilitas menu A'la Carte dengan Kategori Snack di Mentawai Restaurant Pangeran Beach Hotel Padang dengan menggunakan metode menu engineering pada bulan Oktober- Desember 2020 dan Januari - Maret 2021. Adapun hasil analisis dapat dilihat pada Tabel 3.

Tabel 3. Menu Engineering Worksheet Menu A’la Carte kategori Snack

\begin{tabular}{|c|c|c|c|c|c|c|c|c|c|}
\hline $\mathbf{A}$ & $\mathbf{B}$ & $\mathbf{C}$ & D & $\mathbf{E}$ & $\mathbf{F}$ & G & $\mathbf{H}$ & $\mathbf{L}$ & $\mathbf{P}$ \\
\hline $\begin{array}{l}\text { Nama } \\
\text { Item }\end{array}$ & $\begin{array}{l}\text { Numb } \\
\text { er } \\
\text { Sold }\end{array}$ & $\begin{array}{c}\text { Men } \\
\mathrm{u} \\
\mathrm{Mix} \\
\%\end{array}$ & $\begin{array}{c}\text { Item } \\
\text { Food } \\
\text { Cost }\end{array}$ & $\begin{array}{c}\text { Item } \\
\text { Sell } \\
\text { Price }\end{array}$ & $\begin{array}{l}\text { Item } \\
\text { C.M } \\
\text { (E-D) }\end{array}$ & $\begin{array}{l}\text { Total } \\
\text { Cost } \\
\left(D^{*} B\right)\end{array}$ & $\begin{array}{c}\text { Total } \\
\text { Revenue } \\
\left(\mathrm{E}^{*} \mathrm{~B}\right)\end{array}$ & $\begin{array}{c}\text { Total } \\
\text { Profit (H- } \\
\text { G) }\end{array}$ & $\begin{array}{c}\text { Profit } \\
\text { (C.M) } \\
\text { Catego } \\
\text { ry }\end{array}$ \\
\hline $\begin{array}{l}\text { Chicken } \\
\text { Finger }\end{array}$ & 5 & $1 \%$ & $\begin{array}{c}\text { Rp16.1 } \\
75\end{array}$ & $\begin{array}{c}\mathrm{Rp} 52.0 \\
00\end{array}$ & $\begin{array}{c}\text { Rp35.8 } \\
25\end{array}$ & Rp80.875 & Rp260.000 & $\begin{array}{c}\text { Rp179.12 } \\
5\end{array}$ & High \\
\hline $\begin{array}{c}\text { Fish } \\
\text { Finger }\end{array}$ & 0 & $0 \%$ & $\begin{array}{c}\text { Rp19.6 } \\
40\end{array}$ & $\begin{array}{c}\text { Rp52.0 } \\
00\end{array}$ & $\begin{array}{l}\text { Rp32.3 } \\
60\end{array}$ & Rp- & Rp- & Rp- & High \\
\hline
\end{tabular}




\begin{tabular}{|c|c|c|c|c|c|c|c|c|c|}
\hline $\mathbf{A}$ & B & $\mathrm{C}$ & D & $\mathbf{E}$ & $\mathbf{F}$ & G & $\mathbf{H}$ & $\mathbf{L}$ & $P$ \\
\hline $\begin{array}{l}\text { Calamar } \\
\text { y Fritter }\end{array}$ & 9 & $3 \%$ & $\begin{array}{c}\text { Rp19.8 } \\
03\end{array}$ & $\begin{array}{c}\text { Rp52.0 } \\
00\end{array}$ & $\begin{array}{l}\text { Rp32.1 } \\
97\end{array}$ & $\begin{array}{c}\text { Rp178.22 } \\
7\end{array}$ & Rp468.000 & $\begin{array}{c}\text { Rp289.77 } \\
3\end{array}$ & High \\
\hline $\begin{array}{c}\text { Fried } \\
\text { Chicken } \\
\text { Wings }\end{array}$ & 32 & $9 \%$ & $\begin{array}{c}\text { Rp12.7 } \\
43\end{array}$ & $\begin{array}{c}\text { Rp32.0 } \\
00\end{array}$ & $\begin{array}{c}\text { Rp19.2 } \\
57\end{array}$ & $\begin{array}{c}\text { Rp407.77 } \\
6\end{array}$ & $\begin{array}{c}\mathrm{Rp} 1.024 .0 \\
00\end{array}$ & $\begin{array}{c}\text { Rp616.22 } \\
4\end{array}$ & Low \\
\hline $\begin{array}{c}\text { Barbequ } \\
\text { e } \\
\text { Chicken } \\
\text { Wings }\end{array}$ & 11 & $3 \%$ & $\begin{array}{l}\text { Rp14.4 } \\
60\end{array}$ & $\begin{array}{c}\text { Rp32.0 } \\
00\end{array}$ & $\begin{array}{c}\text { Rp17.5 } \\
40\end{array}$ & $\begin{array}{c}\text { Rp159.06 } \\
0\end{array}$ & Rp352.000 & $\begin{array}{c}\text { Rp192.94 } \\
0\end{array}$ & Low \\
\hline $\begin{array}{c}\text { Buffalo } \\
\text { Chicken } \\
\text { Wings }\end{array}$ & 3 & $1 \%$ & $\begin{array}{c}\text { Rp16.5 } \\
16\end{array}$ & $\begin{array}{c}\text { Rp35.0 } \\
00\end{array}$ & $\begin{array}{c}\text { Rp18.4 } \\
84\end{array}$ & Rp49.548 & Rp105.000 & Rp55.452 & Low \\
\hline $\begin{array}{l}\text { Banana } \\
\text { Fritter }\end{array}$ & 2 & $1 \%$ & $\begin{array}{c}\text { Rp9.06 } \\
4\end{array}$ & $\begin{array}{c}\text { Rp35.0 } \\
00\end{array}$ & $\begin{array}{c}\text { Rp25.9 } \\
36\end{array}$ & Rp18.128 & Rp70.000 & Rp51.872 & Low \\
\hline $\begin{array}{l}\text { Chicken } \\
\text { Nugget }\end{array}$ & 38 & $11 \%$ & $\begin{array}{l}\text { Rp8.15 } \\
\quad 6\end{array}$ & $\begin{array}{c}\text { Rp46.0 } \\
00\end{array}$ & $\begin{array}{l}\text { Rp37.8 } \\
44\end{array}$ & $\begin{array}{c}\text { Rp309.92 } \\
8\end{array}$ & $\begin{array}{c}\mathrm{Rp} 1.748 .0 \\
00\end{array}$ & $\begin{array}{c}\text { Rp1.438. } \\
072\end{array}$ & High \\
\hline $\begin{array}{l}\text { French } \\
\text { Fries }\end{array}$ & 230 & $68 \%$ & $\begin{array}{c}\text { Rp10.0 } \\
10\end{array}$ & $\begin{array}{c}\text { Rp35.0 } \\
00\end{array}$ & $\begin{array}{c}\text { Rp24.9 } \\
90\end{array}$ & $\begin{array}{c}\mathrm{Rp} 2.302 . \\
300\end{array}$ & $\begin{array}{c}\text { Rp8.050.0 } \\
00\end{array}$ & $\begin{array}{c}\text { Rp5.747. } \\
700\end{array}$ & Low \\
\hline $\begin{array}{l}\text { French } \\
\text { Fries } \\
\text { and } \\
\text { Sausage }\end{array}$ & 9 & $3 \%$ & $\begin{array}{c}\text { Rp11.7 } \\
86\end{array}$ & $\begin{array}{c}\text { Rp46.0 } \\
00\end{array}$ & $\begin{array}{c}\text { Rp34.2 } \\
14\end{array}$ & $\begin{array}{c}\text { Rp106.07 } \\
4\end{array}$ & Rp414.000 & $\begin{array}{c}\text { Rp307.92 } \\
6\end{array}$ & High \\
\hline $\begin{array}{c}\text { Total } \\
(\mathrm{N}) \\
\text { Total }\end{array}$ & 339 & $\begin{array}{c}100 \\
\%\end{array}$ & & & & I & $\mathrm{J}$ & M & \\
\hline $\begin{array}{l}\text { Menu } \\
\text { Mix }\end{array}$ & 10 & & & & & $\begin{array}{c}\text { Rp3.611. } \\
916\end{array}$ & $\begin{array}{c}\text { Rp12.491. } \\
000\end{array}$ & $\begin{array}{c}\text { Rp8.879. } \\
084\end{array}$ & \\
\hline $\begin{array}{c}\mathrm{K}=\mathrm{I} / \mathrm{J} \\
(\mathrm{Food} \\
\text { Cost \%) } \\
\mathrm{O}=\mathrm{M} / \mathrm{N}\end{array}$ & $29 \%$ & & & & & & & & \\
\hline $\begin{array}{l}\text { (Averag } \\
\text { e Item } \\
\text { Profit) }\end{array}$ & Rp26 & & & & & & & & \\
\hline $\begin{array}{l}\text { Percent } \\
\text { age } \\
\text { Menu } \\
\text { Mix }\end{array}$ & $7 \%$ & & & & & & & & \\
\hline
\end{tabular}

Berdasarkan Tabel 3 diatas dapat dilihat bahwa hasil analisis dari 10 menu di kategori Snack yang memiliki profitabilitas tinggi adalah Chicken Finger, Fish Finger, Calamari Fritter, Chicken Nugget, dan French Fries and Sausage. Analisis selanjutnya dilakukan untuk mengetahui tingkat profitabilitas menu A'la Carte dengan Kategori Pasta and Pizza di Mentawai Restaurant Pangeran Beach Hotel Padang dengan menggunakan metode menu engineering. Hasil analisis penelitian dapat dilihat pada Tabel 4.

Tabel 4. Menu Engineering Worksheet Menu A'la Carte kategori Pasta and Pizza

\begin{tabular}{|c|c|c|c|c|c|c|c|c|c|}
\hline $\mathbf{A}$ & B & C & D & $\mathbf{E}$ & $\mathbf{F}$ & G & $\mathbf{H}$ & $\mathbf{L}$ & $\mathbf{P}$ \\
\hline $\begin{array}{l}\text { Nama } \\
\text { Item }\end{array}$ & $\begin{array}{l}\text { Numb } \\
\text { er } \\
\text { Sold }\end{array}$ & $\begin{array}{c}\text { Men } \\
\mathrm{u} \\
\mathrm{Mix} \\
\%\end{array}$ & $\begin{array}{l}\text { Item } \\
\text { Food } \\
\text { Cost }\end{array}$ & $\begin{array}{l}\text { Item } \\
\text { Sell } \\
\text { Price }\end{array}$ & $\begin{array}{l}\text { Item } \\
\text { C.M } \\
\text { (E-D) }\end{array}$ & $\begin{array}{c}\text { Total } \\
\text { Cost } \\
\text { (D*B) }\end{array}$ & $\begin{array}{c}\text { Total } \\
\text { Revenue } \\
\left(E^{*} B\right)\end{array}$ & $\begin{array}{c}\text { Total } \\
\text { Profit (H- } \\
\text { G) }\end{array}$ & $\begin{array}{c}\text { Profit } \\
\text { (C.M) } \\
\text { Catego } \\
\text { ry }\end{array}$ \\
\hline
\end{tabular}




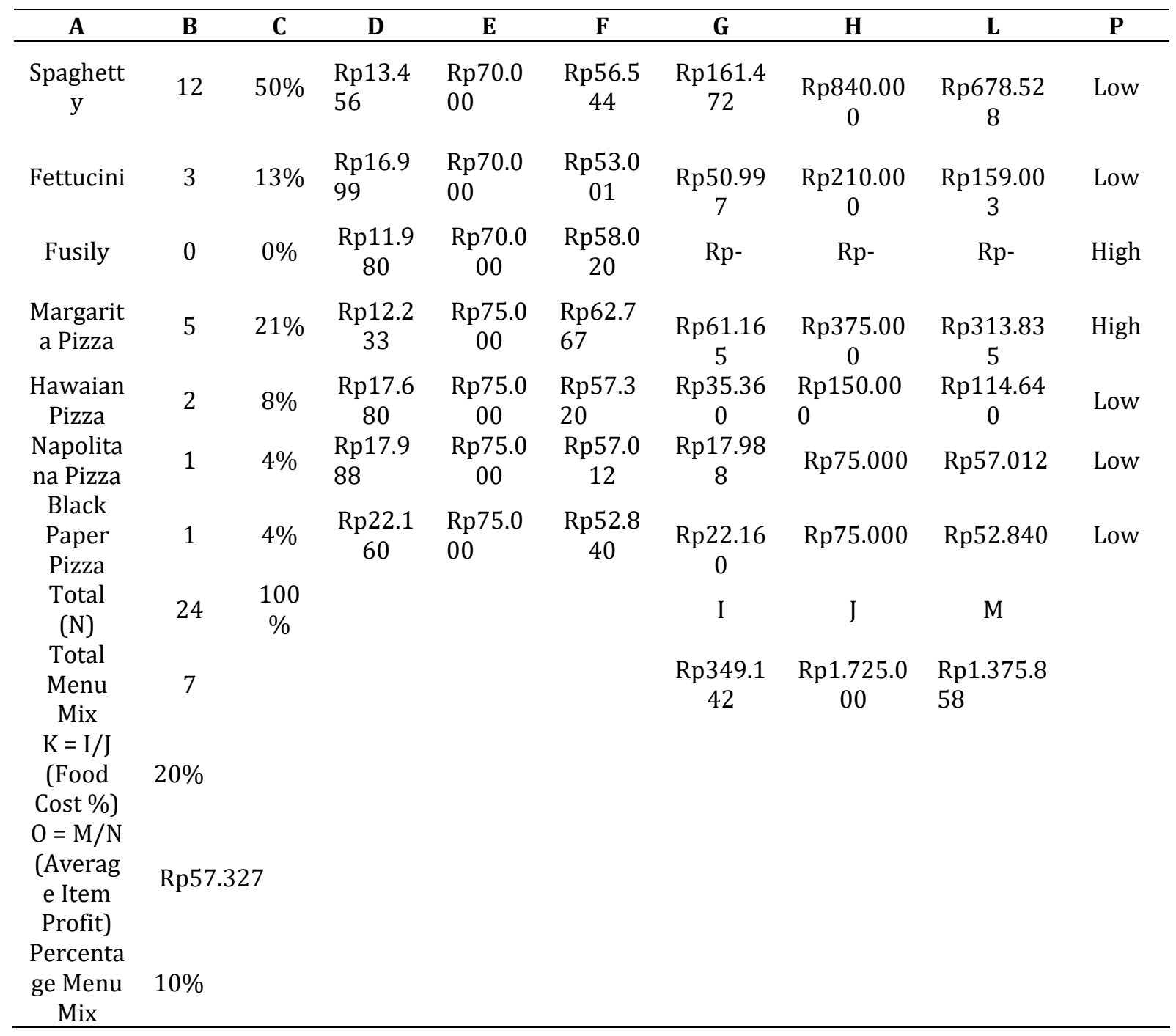

Berdasarkan Tabel 4 diatas dapat dilihat bahwa hasil analisis dari 7 menu di kategori Pasta and Pizza yang memiliki profitabilitas tinggi adalah Fusilli dan Margarita Pizza. Analisis selanjutnya dilakukan untuk mengetahui tingkat profitabilitas menu A'la Carte dengan Kategori Salad di Mentawai Restaurant Pangeran Beach Hotel Padang dengan menggunakan metode menu engineering. Adapun hasil analisis penelitian dapat dilihat pada Tabel 5 .

Tabel 5. Menu Engineering Worksheet Menu A'la Carte kategori Salad

\begin{tabular}{|c|c|c|c|c|c|c|c|c|c|}
\hline A & B & $\mathrm{C}$ & D & $E$ & $F$ & G & H & $L$ & $\mathbf{P}$ \\
\hline $\begin{array}{l}\text { Nama } \\
\text { Item }\end{array}$ & $\begin{array}{l}\text { Numb } \\
\text { er } \\
\text { Sold }\end{array}$ & $\begin{array}{c}\text { Men } \\
\mathrm{u} \\
\mathrm{Mix} \\
\%\end{array}$ & $\begin{array}{l}\text { Item } \\
\text { Food } \\
\text { Cost }\end{array}$ & $\begin{array}{l}\text { Item } \\
\text { Sell } \\
\text { Price }\end{array}$ & $\begin{array}{l}\text { Item } \\
\text { C.M } \\
\text { (E-D) }\end{array}$ & $\begin{array}{c}\text { Total } \\
\text { Cost } \\
\left(D^{*} B\right)\end{array}$ & $\begin{array}{c}\text { Total } \\
\text { Revenue } \\
\left(E^{*} B\right)\end{array}$ & $\begin{array}{l}\text { Total } \\
\text { Profit } \\
\text { (H-G) }\end{array}$ & $\begin{array}{c}\text { Profit } \\
\text { (C.M) } \\
\text { Catego } \\
\text { ry }\end{array}$ \\
\hline $\begin{array}{l}\text { Cheft } \\
\text { Salad }\end{array}$ & 2 & $11 \%$ & $\begin{array}{c}\text { Rp17.1 } \\
35\end{array}$ & $\begin{array}{c}\text { Rp46.0 } \\
00\end{array}$ & $\begin{array}{c}\text { Rp28.8 } \\
65\end{array}$ & $\begin{array}{c}\mathrm{Rp} 34.27 \\
0\end{array}$ & $\begin{array}{c}\text { Rp92.00 } \\
0\end{array}$ & $\begin{array}{c}\text { Rp57.73 } \\
0\end{array}$ & Low \\
\hline $\begin{array}{l}\text { Exotic } \\
\text { Fruits } \\
\text { Salad }\end{array}$ & 4 & $\begin{array}{c}133 \\
\%\end{array}$ & $\begin{array}{l}\text { Rp19.8 } \\
43\end{array}$ & $\begin{array}{c}\text { Rp46.0 } \\
00\end{array}$ & $\begin{array}{c}\text { Rp26.1 } \\
57\end{array}$ & $\begin{array}{c}\text { Rp79.37 } \\
2\end{array}$ & $\begin{array}{c}\mathrm{Rp} 184.0 \\
00\end{array}$ & $\begin{array}{c}\mathrm{Rp} 104.6 \\
28\end{array}$ & Low \\
\hline $\begin{array}{l}\text { Gado- } \\
\text { Gado }\end{array}$ & 13 & $68 \%$ & $\begin{array}{l}\text { Rp8.31 } \\
\quad 6\end{array}$ & $\begin{array}{c}\text { Rp46.0 } \\
00\end{array}$ & $\begin{array}{c}\text { Rp37.6 } \\
84\end{array}$ & $\begin{array}{c}\text { Rp108.1 } \\
08\end{array}$ & $\begin{array}{c}\text { Rp598.0 } \\
00\end{array}$ & $\begin{array}{c}\text { Rp489.8 } \\
92\end{array}$ & High \\
\hline Total (N) & 19 & $\begin{array}{c}212 \\
\%\end{array}$ & & & & I & $\mathrm{J}$ & M & \\
\hline
\end{tabular}




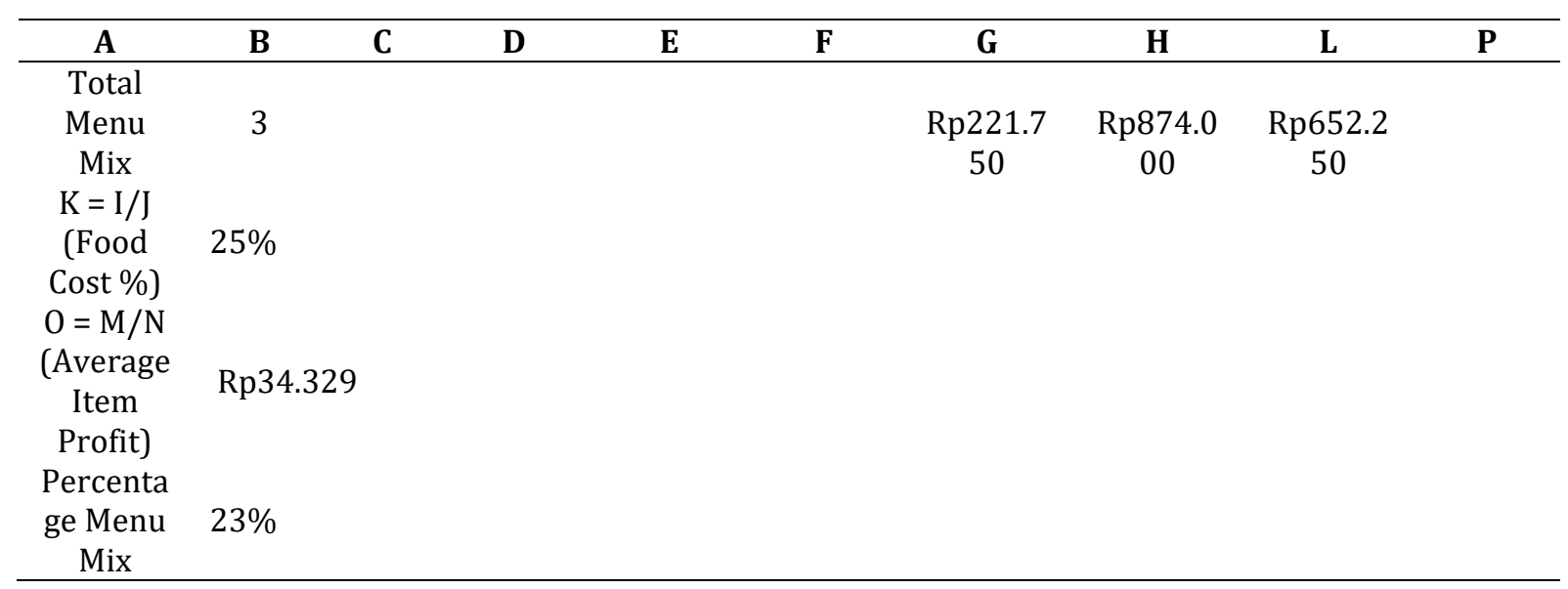

Berdasarkan Tabel 5 diatas dapat dilihat bahwa 3 menu di kategori Salad yang memiliki profitabilitas tinggi adalah Gado-Gado. Penelitian selanjutnya dilakukan untuk mengetahui tingkat profitabilitas menu A'la Carte dengan Kategori Western Favorites di Mentawai Restaurant Pangeran Beach Hotel Padang dengan menggunakan metode menu engineering. Hasil analisis disajikan pada Tabel 6.

Tabel 6. Menu Engineering Worksheet Menu A'la Carte kategori Western Favorites

\begin{tabular}{|c|c|c|c|c|c|c|c|c|c|}
\hline A & B & C & D & $\mathbf{E}$ & $\mathbf{F}$ & G & $\mathbf{H}$ & L & $\mathbf{P}$ \\
\hline $\begin{array}{l}\text { Nama } \\
\text { Item }\end{array}$ & $\begin{array}{l}\text { Num } \\
\text { ber } \\
\text { Sold }\end{array}$ & $\begin{array}{c}\text { Men } \\
\text { u } \\
\text { Mix } \\
\%\end{array}$ & $\begin{array}{l}\text { Item } \\
\text { Food } \\
\text { Cost }\end{array}$ & $\begin{array}{l}\text { Item } \\
\text { Sell } \\
\text { Price }\end{array}$ & $\begin{array}{c}\text { Item } \\
\text { C.M } \\
\text { (E-D) }\end{array}$ & $\begin{array}{c}\text { Total } \\
\text { Cost } \\
\left(D^{*} B\right)\end{array}$ & $\begin{array}{c}\text { Total } \\
\text { Revenue } \\
\left(\mathrm{E}^{*} \mathrm{~B}\right)\end{array}$ & $\begin{array}{c}\text { Total } \\
\text { Profit (H- } \\
\text { G) }\end{array}$ & $\begin{array}{c}\text { Profit } \\
\text { (C.M) } \\
\text { Catego } \\
\text { ry }\end{array}$ \\
\hline $\begin{array}{c}\text { Grill Beef } \\
\text { Tenderloi } \\
\text { n Steak }\end{array}$ & 9 & $41 \%$ & $\begin{array}{c}\text { Rp55.3 } \\
12\end{array}$ & $\begin{array}{c}\text { Rp } 145.0 \\
00\end{array}$ & $\begin{array}{c}\text { Rp89.68 } \\
8\end{array}$ & $\begin{array}{c}\text { Rp497.8 } \\
08\end{array}$ & $\begin{array}{c}\text { Rp1.305. } \\
000\end{array}$ & $\begin{array}{c}\text { Rp807.19 } \\
2\end{array}$ & High \\
\hline $\begin{array}{c}\text { Grill Beef } \\
\text { Sirloin } \\
\text { Steak } \\
\text { Grill }\end{array}$ & 0 & $0 \%$ & $\begin{array}{l}\text { Rp47.1 } \\
46\end{array}$ & $\begin{array}{c}\text { Rp } 145.0 \\
00\end{array}$ & $\begin{array}{c}\text { Rp97.85 } \\
4\end{array}$ & Rp- & Rp- & Rp- & High \\
\hline $\begin{array}{c}\text { Chicken } \\
\text { Steak }\end{array}$ & 5 & $23 \%$ & $\begin{array}{c}\mathrm{p} 24.95 \\
2\end{array}$ & $\begin{array}{c}\mathrm{p} 127.00 \\
0\end{array}$ & $\begin{array}{c}\text { Rp102.0 } \\
48\end{array}$ & $\begin{array}{c}\mathrm{Rp} 124.7 \\
60\end{array}$ & $\begin{array}{c}\text { Rp635.00 } \\
0\end{array}$ & $\begin{array}{c}\text { Rp510.24 } \\
0\end{array}$ & High \\
\hline $\begin{array}{l}\text { Grill Fish } \\
\text { Snapper }\end{array}$ & 0 & $0 \%$ & $\begin{array}{l}\text { p35.11 } \\
4\end{array}$ & $\begin{array}{c}\text { Rp87.00 } \\
0\end{array}$ & $\begin{array}{c}\text { Rp51.88 } \\
6\end{array}$ & Rp- & Rp- & Rp- & Low \\
\hline $\begin{array}{c}\text { Chicken } \\
\text { Gordon } \\
\text { Blue }\end{array}$ & 5 & $23 \%$ & $\begin{array}{c}\text { Rp38.0 } \\
39\end{array}$ & $\begin{array}{c}\mathrm{Rp} 87.00 \\
0\end{array}$ & $\begin{array}{c}\text { Rp48.96 } \\
1\end{array}$ & $\begin{array}{c}\text { Rp190.1 } \\
95\end{array}$ & $\begin{array}{c}\mathrm{Rp} 435.00 \\
0\end{array}$ & $\begin{array}{c}\mathrm{Rp} 244.80 \\
5\end{array}$ & Low \\
\hline $\begin{array}{l}\text { Fish and } \\
\text { Chips }\end{array}$ & 3 & $14 \%$ & $\begin{array}{c}\operatorname{Rp} 16.8 \\
69\end{array}$ & $\begin{array}{l}\text { Rp70.00 } \\
0\end{array}$ & $\begin{array}{c}\text { Rp53.13 } \\
1\end{array}$ & $\begin{array}{c}\mathrm{Rp} 50.60 \\
7\end{array}$ & $\begin{array}{c}\mathrm{Rp} 210.00 \\
0\end{array}$ & $\begin{array}{c}\text { Rp159.39 } \\
3\end{array}$ & Low \\
\hline Total (N) & 22 & $\begin{array}{c}100 \\
\%\end{array}$ & & & & I & $\mathrm{J}$ & M & \\
\hline $\begin{array}{c}\text { Total } \\
\text { Menu Mix }\end{array}$ & 6 & & & & & $\begin{array}{c}\text { Rp863.3 } \\
70\end{array}$ & $\begin{array}{c}\text { Rp2.585. } \\
000\end{array}$ & $\begin{array}{c}\text { Rp1.721. } \\
630\end{array}$ & \\
\hline $\begin{array}{c}\mathrm{K}=\mathrm{I} / \mathrm{J} \\
\text { (Food } \\
\text { Cost \%) } \\
\mathrm{O}=\mathrm{M} / \mathrm{N}\end{array}$ & & & & & & & & & $33 \%$ \\
\hline $\begin{array}{l}\text { (Averag } \\
\text { e Item } \\
\text { Profit) }\end{array}$ & & & & & & & & & Rp78.256 \\
\hline $\begin{array}{l}\text { Percent } \\
\text { age } \\
\text { Menu } \\
\text { Mix } \\
\end{array}$ & & & & & & & & & $12 \%$ \\
\hline
\end{tabular}


Berdasarkan Tabel 6 dapat dilihat bahwa dari 6 menu di kategori Western Favorites yang memiliki profitabilitas tinggi adalah Grill Beef Tenderloin Steak, Grill Beef Sirloin Steak, Grill Chicken Steak. Penelitian selanjutnya dilakukan untuk mengetahui tingkat profitabilitas menu A'la Carte dengan Kategori Burger di Mentawai Restaurant Pangeran Beach Hotel Padang dengan menggunakan metode menu engineering. Adapun hasil analisis disajikan pada Tabel 7.

Tabel 7. Menu Engineering Worksheet Menu A'la Carte kategori Burger

\begin{tabular}{|c|c|c|c|c|c|c|c|c|c|}
\hline $\mathbf{A}$ & B & $\mathrm{C}$ & D & $\mathbf{E}$ & $\mathbf{F}$ & $\mathbf{G}$ & $\mathbf{H}$ & $\mathbf{L}$ & $\mathbf{P}$ \\
\hline $\begin{array}{l}\text { Nama } \\
\text { Item }\end{array}$ & $\begin{array}{l}\text { Numb } \\
\text { er } \\
\text { Sold }\end{array}$ & $\begin{array}{c}\text { Men } \\
\text { u } \\
\text { Mix } \\
\%\end{array}$ & $\begin{array}{l}\text { Item } \\
\text { Food } \\
\text { Cost }\end{array}$ & $\begin{array}{c}\text { Item } \\
\text { Sell } \\
\text { Price }\end{array}$ & $\begin{array}{l}\text { Item } \\
\text { C.M } \\
\text { (E-D) }\end{array}$ & $\begin{array}{l}\text { Total } \\
\text { Cost } \\
\left(D^{*} B\right)\end{array}$ & $\begin{array}{c}\text { Total } \\
\text { Revenue } \\
\left(\mathrm{E}^{*} \mathrm{~B}\right)\end{array}$ & $\begin{array}{l}\text { Total } \\
\text { Profit } \\
(\mathrm{H}-\mathrm{G})\end{array}$ & $\begin{array}{l}\text { Profit } \\
\text { (C.M) } \\
\text { Catego } \\
\text { ry }\end{array}$ \\
\hline $\begin{array}{c}\text { Barbequ } \\
\text { e } \\
\text { Mushroo } \\
\text { m } \\
\text { Cheese } \\
\text { Burger }\end{array}$ & 5 & $\begin{array}{c}250 \\
\%\end{array}$ & $\begin{array}{c}\text { Rp23.4 } \\
36\end{array}$ & $\begin{array}{c}\text { Rp80.0 } \\
00\end{array}$ & $\begin{array}{l}\operatorname{Rp} 56.5 \\
64\end{array}$ & $\begin{array}{c}\text { Rp117.1 } \\
80\end{array}$ & $\begin{array}{c}\mathrm{Rp} 400.0 \\
00\end{array}$ & $\begin{array}{c}\text { Rp282.8 } \\
20\end{array}$ & Low \\
\hline $\begin{array}{c}\text { Beef } \\
\text { Burger }\end{array}$ & 4 & $\begin{array}{c}200 \\
\%\end{array}$ & $\begin{array}{l}\text { Rp18.2 } \\
82\end{array}$ & $\begin{array}{l}\text { Rp77.0 } \\
00\end{array}$ & $\begin{array}{l}\operatorname{Rp} 58.7 \\
18\end{array}$ & $\begin{array}{c}\text { Rp73.12 } \\
8\end{array}$ & $\begin{array}{l}\text { Rp308.0 } \\
00\end{array}$ & $\begin{array}{l}\text { Rp234.8 } \\
72\end{array}$ & Low \\
\hline $\begin{array}{l}\text { Chicken } \\
\text { Burger }\end{array}$ & 1 & $50 \%$ & $\begin{array}{l}\text { Rp13.3 } \\
21\end{array}$ & $\begin{array}{l}\text { Rp65.0 } \\
00\end{array}$ & $\begin{array}{l}\text { Rp51.6 } \\
79\end{array}$ & $\begin{array}{c}\mathrm{Rp} 13.32 \\
1\end{array}$ & $\begin{array}{c}\text { Rp65.00 } \\
0\end{array}$ & $\begin{array}{c}\text { Rp51.67 } \\
9\end{array}$ & Low \\
\hline Total (N) & 2 & $\begin{array}{c}500 \\
\%\end{array}$ & & & & I & J & M & \\
\hline $\begin{array}{l}\text { Total } \\
\text { Menu } \\
\text { Mix }\end{array}$ & 3 & & & & & $\begin{array}{l}\text { Rp203.6 } \\
29\end{array}$ & $\begin{array}{l}\text { Rp773.0 } \\
00\end{array}$ & $\begin{array}{l}\text { Rp569.3 } \\
71\end{array}$ & \\
\hline $\begin{array}{c}\mathrm{K}=\mathrm{l} / \mathrm{J} \\
(\mathrm{Food} \\
\text { Cost \%) } \\
\mathrm{O}=\mathrm{M} / \mathrm{N}\end{array}$ & & & & & & & & & $26 \%$ \\
\hline $\begin{array}{c}\text { (Average } \\
\text { Item } \\
\text { Profit) }\end{array}$ & & & & & & & & & 284.686 \\
\hline $\begin{array}{l}\text { Percenta } \\
\text { ge Menu } \\
\text { Mix }\end{array}$ & & & & & & & & & $23 \%$ \\
\hline
\end{tabular}

Berdasarkan Tabel 7 diatas dapat dilihat bahwa dari 3 menu di kategori Burger tidak ada yang memiliki profitabilitas tinggi. Penelitian selanjutnya dilakukan untuk mengetahui tingkat profitabilitas menu A'la Carte dengan Kategori Asian Dishes di Mentawai Restaurant Pangeran Beach Hotel Padang dengan menggunakan metode menu engineering. Adapun hasil analisis penelitian dapat dilihat pada Tabel 8.

Tabel 8. Menu Engineering Worksheet Menu A'la Carte kategori Asian Dishes

\begin{tabular}{|c|c|c|c|c|c|c|c|c|c|}
\hline $\mathbf{A}$ & B & C & D & $\mathbf{E}$ & $\mathbf{F}$ & G & $\mathbf{H}$ & $\mathbf{L}$ & $\mathbf{P}$ \\
\hline $\begin{array}{l}\text { Nama } \\
\text { Item }\end{array}$ & $\begin{array}{l}\text { Numb } \\
\text { er } \\
\text { Sold }\end{array}$ & $\begin{array}{c}\text { Men } \\
\text { u } \\
\text { Mix } \\
\%\end{array}$ & $\begin{array}{l}\text { Item } \\
\text { Food } \\
\text { Cost }\end{array}$ & $\begin{array}{c}\text { Item } \\
\text { Sell } \\
\text { Price }\end{array}$ & $\begin{array}{l}\text { Item } \\
\text { C.M } \\
\text { (E-D) }\end{array}$ & $\begin{array}{l}\text { Total } \\
\text { Cost } \\
\left(D^{*} B\right)\end{array}$ & $\begin{array}{c}\text { Total } \\
\text { Revenue } \\
\left(E^{*} B\right)\end{array}$ & $\begin{array}{c}\text { Total } \\
\text { Profit (H- } \\
\text { G) }\end{array}$ & $\begin{array}{c}\text { Profit } \\
\text { (C.M) } \\
\text { Catego } \\
\text { ry }\end{array}$ \\
\hline $\begin{array}{c}\text { Nasi } \\
\text { Goreng } \\
\text { Seafood }\end{array}$ & 37 & $7 \%$ & $\begin{array}{l}\text { Rp15.7 } \\
25\end{array}$ & $\begin{array}{c}\mathrm{Rp} 60.00 \\
0\end{array}$ & $\begin{array}{c}\text { Rp44.2 } \\
75\end{array}$ & $\begin{array}{c}\text { Rp581.82 } \\
5\end{array}$ & $\begin{array}{c}\mathrm{Rp} 2.220 .0 \\
00\end{array}$ & $\begin{array}{c}\text { Rp1.638.1 } \\
75\end{array}$ & Low \\
\hline $\begin{array}{l}\text { Nasi } \\
\text { Goreng } \\
\text { Buntut }\end{array}$ & 12 & $2 \%$ & $\begin{array}{c}\text { Rp24.1 } \\
32\end{array}$ & $\begin{array}{l}\text { Rp90.00 } \\
0\end{array}$ & $\begin{array}{l}\text { Rp65.8 } \\
68\end{array}$ & $\begin{array}{l}\text { Rp289.58 } \\
4\end{array}$ & $\begin{array}{c}\text { Rp1.080.0 } \\
00\end{array}$ & $\begin{array}{c}\text { Rp790.41 } \\
6\end{array}$ & High \\
\hline
\end{tabular}




\begin{tabular}{|c|c|c|c|c|c|c|c|c|c|}
\hline A & B & $\mathrm{C}$ & D & $\mathbf{E}$ & $\mathbf{F}$ & $\mathbf{G}$ & $\mathbf{H}$ & $\mathbf{L}$ & $\mathbf{P}$ \\
\hline $\begin{array}{c}\text { Nasi } \\
\text { Goreng } \\
\text { Ikan } \\
\text { Asin }\end{array}$ & 20 & $4 \%$ & $\begin{array}{l}\text { Rp10.9 } \\
12\end{array}$ & $\begin{array}{c}\mathrm{Rp} 55.00 \\
0\end{array}$ & $\begin{array}{l}\text { Rp44.0 } \\
88\end{array}$ & $\begin{array}{c}\text { Rp2 } 18.24 \\
0\end{array}$ & $\begin{array}{c}\mathrm{Rp} 1.100 .0 \\
00\end{array}$ & $\begin{array}{c}\text { Rp881.76 } \\
0\end{array}$ & Low \\
\hline $\begin{array}{c}\text { Nasi } \\
\text { Goreng } \\
\text { Pangera } \\
\text { n }\end{array}$ & 241 & $\begin{array}{l}49 \\
\%\end{array}$ & $\begin{array}{l}\text { Rp12.6 } \\
50\end{array}$ & $\begin{array}{c}\text { Rp60.00 } \\
0\end{array}$ & $\begin{array}{l}\text { Rp47.3 } \\
50\end{array}$ & $\begin{array}{c}\text { Rp3.048. } \\
650\end{array}$ & $\begin{array}{c}\text { Rp14.460. } \\
000\end{array}$ & $\begin{array}{c}\text { Rp11.411. } \\
350\end{array}$ & Low \\
\hline $\begin{array}{c}\text { Mie } \\
\text { Goreng }\end{array}$ & 57 & $\begin{array}{l}12 \\
\%\end{array}$ & $\begin{array}{l}\text { Rp14.2 } \\
06\end{array}$ & $\begin{array}{c}\text { Rp55.00 } \\
0\end{array}$ & $\begin{array}{l}\text { Rp40.7 } \\
94\end{array}$ & $\begin{array}{c}\text { Rp809.74 } \\
2\end{array}$ & $\begin{array}{c}\mathrm{Rp} 3.135 .0 \\
00\end{array}$ & $\begin{array}{c}\text { Rp2.325.2 } \\
58\end{array}$ & Low \\
\hline $\begin{array}{l}\text { Bihun } \\
\text { Goreng }\end{array}$ & 4 & $1 \%$ & $\begin{array}{l}\text { Rp15.0 } \\
22\end{array}$ & $\begin{array}{c}\text { Rp55.00 } \\
0\end{array}$ & $\begin{array}{l}\text { Rp39.9 } \\
78\end{array}$ & Rp60.088 & $\begin{array}{c}\mathrm{Rp} 220.00 \\
0\end{array}$ & $\begin{array}{c}\text { Rp159.91 } \\
2\end{array}$ & Low \\
\hline $\begin{array}{l}\text { Kwetiau } \\
\text { Goreng }\end{array}$ & 11 & $2 \%$ & $\begin{array}{l}\operatorname{Rp} 11.0 \\
67\end{array}$ & $\begin{array}{c}\text { Rp55.00 } \\
0\end{array}$ & $\begin{array}{l}\text { Rp43.9 } \\
33\end{array}$ & $\begin{array}{c}\text { Rp121.73 } \\
7\end{array}$ & $\begin{array}{c}\mathrm{Rp} 605.00 \\
0\end{array}$ & $\begin{array}{c}\mathrm{Rp} 483.26 \\
3\end{array}$ & Low \\
\hline $\begin{array}{c}\text { Sate } \\
\text { Ayam }\end{array}$ & 4 & $1 \%$ & $\begin{array}{c}\mathrm{Rp} \\
9.951\end{array}$ & $\begin{array}{c}\text { Rp55.00 } \\
0\end{array}$ & $\begin{array}{l}\operatorname{Rp} 45.0 \\
49\end{array}$ & Rp39.804 & $\begin{array}{c}\mathrm{Rp} 220.00 \\
0\end{array}$ & $\begin{array}{c}\text { Rp180.19 } \\
6\end{array}$ & Low \\
\hline $\begin{array}{c}\text { Sate } \\
\text { Daging }\end{array}$ & 5 & $1 \%$ & $\begin{array}{l}\text { Rp17.5 } \\
56\end{array}$ & $\begin{array}{c}\text { Rp55.00 } \\
0\end{array}$ & $\begin{array}{l}\text { Rp37.4 } \\
44\end{array}$ & Rp87.780 & $\begin{array}{c}\mathrm{Rp} 275.00 \\
0\end{array}$ & $\begin{array}{c}\text { Rp187.22 } \\
0\end{array}$ & Low \\
\hline $\begin{array}{c}\text { Sate } \\
\text { Marang } \\
\text { gi }\end{array}$ & 12 & $2 \%$ & $\begin{array}{l}\text { Rp19.9 } \\
94\end{array}$ & $\begin{array}{c}\text { Rp55.00 } \\
0\end{array}$ & $\begin{array}{l}\text { Rp35.0 } \\
06\end{array}$ & $\begin{array}{c}\text { Rp239.92 } \\
8\end{array}$ & $\begin{array}{c}\mathrm{Rp} 660.00 \\
0\end{array}$ & $\begin{array}{c}\text { Rp420.07 } \\
2\end{array}$ & Low \\
\hline $\begin{array}{c}\text { Seafood } \\
\text { Sapo } \\
\text { Tahu }\end{array}$ & 1 & $0 \%$ & $\begin{array}{l}\text { Rp18.3 } \\
45\end{array}$ & $\begin{array}{c}\text { Rp70.00 } \\
0\end{array}$ & $\begin{array}{c}\text { Rp51.6 } \\
55\end{array}$ & Rp18.345 & Rp70.000 & Rp51.655 & High \\
\hline $\begin{array}{c}\text { Gurame } \\
\text { Asam } \\
\text { Manis }\end{array}$ & 3 & $1 \%$ & $\begin{array}{l}\text { Rp25.3 } \\
30\end{array}$ & $\begin{array}{l}\text { Rp105.0 } \\
00\end{array}$ & $\begin{array}{l}\text { Rp79.6 } \\
70\end{array}$ & Rp75.990 & $\begin{array}{c}\mathrm{Rp} 315.00 \\
0\end{array}$ & $\begin{array}{c}\mathrm{Rp} 239.01 \\
0\end{array}$ & High \\
\hline $\begin{array}{c}\text { Udang } \\
\text { Goreng } \\
\text { Mayona } \\
\text { ise }\end{array}$ & 3 & $1 \%$ & $\begin{array}{l}\text { Rp14.9 } \\
03\end{array}$ & $\begin{array}{c}\text { Rp86.00 } \\
0\end{array}$ & $\begin{array}{l}\text { Rp71.0 } \\
97\end{array}$ & Rp44.709 & $\begin{array}{c}\text { Rp258.00 } \\
0\end{array}$ & $\begin{array}{c}\mathrm{Rp} 213.29 \\
1\end{array}$ & High \\
\hline $\begin{array}{c}\text { Daging } \\
\text { Sapi } \\
\text { Lada } \\
\text { Hitam }\end{array}$ & 4 & $1 \%$ & $\begin{array}{l}\text { Rp23.3 } \\
03\end{array}$ & $\begin{array}{c}\text { Rp } 95.00 \\
0\end{array}$ & $\begin{array}{l}\text { Rp71.6 } \\
97\end{array}$ & Rp93.212 & $\begin{array}{c}\mathrm{Rp} 380.00 \\
0\end{array}$ & $\begin{array}{c}\text { Rp286.78 } \\
8\end{array}$ & High \\
\hline $\begin{array}{l}\text { Ayam } \\
\text { Bakar } \\
\text { Cabe } \\
\text { Hijau }\end{array}$ & 4 & $1 \%$ & $\begin{array}{c}\text { Rp11.4 } \\
97\end{array}$ & $\begin{array}{c}\text { Rp88.00 } \\
0\end{array}$ & $\begin{array}{c}\text { Rp76.5 } \\
03\end{array}$ & Rp45.988 & $\begin{array}{c}\text { Rp352.00 } \\
0\end{array}$ & $\begin{array}{c}\text { Rp306.01 } \\
2\end{array}$ & High \\
\hline $\begin{array}{c}\text { Gurame } \\
\text { Bakar } \\
\text { Beach }\end{array}$ & 2 & $0 \%$ & $\begin{array}{c}\text { Rp16.1 } \\
59\end{array}$ & $\begin{array}{l}\text { Rp105.0 } \\
00\end{array}$ & $\begin{array}{c}\mathrm{Rp} 88.8 \\
41\end{array}$ & Rp32.318 & $\begin{array}{c}\mathrm{Rp} 210.00 \\
0\end{array}$ & $\begin{array}{c}\text { Rp} 177.68 \\
2\end{array}$ & High \\
\hline $\begin{array}{l}\text { Rendan } \\
\text { g } \\
\text { Padang } \\
\text { Denden }\end{array}$ & 9 & $2 \%$ & $\begin{array}{l}\text { Rp10.4 } \\
71\end{array}$ & $\begin{array}{c}\text { Rp87.00 } \\
0\end{array}$ & $\begin{array}{l}\text { Rp76.5 } \\
29\end{array}$ & Rp94.239 & $\begin{array}{c}\text { Rp783.00 } \\
0\end{array}$ & $\begin{array}{c}\text { Rp688.76 } \\
1\end{array}$ & High \\
\hline $\begin{array}{c}\mathrm{g} \\
\text { Balado } \\
\text { Pangera } \\
\mathrm{n}\end{array}$ & 43 & $9 \%$ & $\begin{array}{l}\text { Rp15.9 } \\
61\end{array}$ & $\begin{array}{c}\text { Rp99.00 } \\
0\end{array}$ & $\begin{array}{l}\text { Rp83.0 } \\
39\end{array}$ & $\begin{array}{c}\text { Rp686.32 } \\
3\end{array}$ & $\begin{array}{c}\mathrm{Rp} 4.257 .0 \\
00\end{array}$ & $\begin{array}{c}\text { Rp3.570.6 } \\
77\end{array}$ & High \\
\hline $\begin{array}{c}\text { Mie } \\
\text { Rebus }\end{array}$ & 13 & $3 \%$ & $\begin{array}{c}\text { Rp14.2 } \\
06\end{array}$ & $\begin{array}{c}\text { Rp55.00 } \\
0\end{array}$ & $\begin{array}{c}\mathrm{Rp} 40.7 \\
94\end{array}$ & $\begin{array}{c}\text { Rp184.67 } \\
8\end{array}$ & $\begin{array}{c}\text { Rp715.00 } \\
0\end{array}$ & $\begin{array}{c}\text { Rp530.32 } \\
2\end{array}$ & Low \\
\hline
\end{tabular}




\begin{tabular}{|c|c|c|c|c|c|c|c|c|c|}
\hline A & B & C & D & $\mathbf{E}$ & $\mathbf{F}$ & G & $\mathbf{H}$ & $\mathbf{L}$ & $\mathbf{P}$ \\
\hline $\begin{array}{c}\text { Cah } \\
\text { Tauge } \\
\text { Ikan } \\
\text { Asin }\end{array}$ & 2 & $0 \%$ & $\begin{array}{c}\text { Rp4.86 } \\
7\end{array}$ & $\begin{array}{c}\mathrm{Rp} 52.00 \\
0\end{array}$ & $\begin{array}{l}\text { Rp47.1 } \\
33\end{array}$ & Rp9.734 & $\begin{array}{c}\mathrm{Rp} 104.00 \\
0\end{array}$ & Rp94.266 & Low \\
\hline $\begin{array}{c}\text { Kangku } \\
\text { ng } \\
\text { Belacan }\end{array}$ & 1 & $0 \%$ & $\begin{array}{c}\text { Rp } 6.92 \\
6\end{array}$ & $\begin{array}{c}\operatorname{Rp} 52.00 \\
0\end{array}$ & $\begin{array}{l}\text { Rp45.0 } \\
74\end{array}$ & Rp6.926 & Rp52.000 & Rp45.074 & Low \\
\hline $\begin{array}{c}\text { Seafood } \\
\text { Capcay }\end{array}$ & 6 & $1 \%$ & $\begin{array}{l}\text { Rp13.8 } \\
31\end{array}$ & $\begin{array}{c}\operatorname{Rp} 52.00 \\
0\end{array}$ & $\begin{array}{c}\text { Rp38.1 } \\
69\end{array}$ & Rp82.986 & $\begin{array}{c}\mathrm{Rp} 312.00 \\
0\end{array}$ & $\begin{array}{c}\mathrm{Rp} 229.01 \\
4\end{array}$ & Low \\
\hline $\begin{array}{c}\text { Cah } \\
\text { Brokoll } \\
\text { y }\end{array}$ & 0 & $0 \%$ & $\begin{array}{l}\text { Rp11.4 } \\
17\end{array}$ & $\begin{array}{c}\operatorname{Rp} 52.00 \\
0\end{array}$ & $\begin{array}{l}\text { Rp40.5 } \\
83\end{array}$ & Rp- & Rp- & Rp- & Low \\
\hline $\begin{array}{l}\text { Total } \\
\text { (N) }\end{array}$ & 494 & $\begin{array}{c}100 \\
\%\end{array}$ & & & & I & $\mathrm{J}$ & $\mathrm{M}$ & \\
\hline $\begin{array}{l}\text { Total } \\
\text { Menu } \\
\text { Mix }\end{array}$ & 23 & & & & & $\begin{array}{c}\text { Rp6.872. } \\
826\end{array}$ & $\begin{array}{c}\text { Rp31.783. } \\
000\end{array}$ & $\begin{array}{c}\mathrm{Rp} 24.910 . \\
174\end{array}$ & \\
\hline $\begin{array}{c}\mathrm{K}=\mathrm{I} / \mathrm{J} \\
\text { (Food } \\
\text { Cost \%) }\end{array}$ & $22 \%$ & & & & & & & & \\
\hline $\begin{array}{l}\mathrm{O}=\mathrm{M} / \mathrm{N} \\
\text { (Averag } \\
\text { e Item } \\
\text { Profit) }\end{array}$ & Rp50 & & & & & & & & \\
\hline $\begin{array}{c}\text { Percent } \\
\text { age } \\
\text { Menu } \\
\text { Mix }\end{array}$ & $3 \%$ & & & & & & & & \\
\hline
\end{tabular}

Berdasarkan tabel 8 diatas dapat dilihat bahwa dari 23 menu di kategori Asian Dishes yang memiliki profitabilitas tinggi adalah : Nasi Goreng Buntut, Seafood Sapo Tahu, Gurame Asam Manis, Udang Goreng Mayonaise, Daging Sapi Lada Hitam, Ayam Bakar Cabe Hijau, Gurame Bakar Beach, Rendang Padang dan Dendeng Balado. Analisis selanjutnya dilakukan untuk mengetahui tingkat profitabilitas menu A'la Carte dengan Kategori Selection Juice di Mentawai Restaurant Pangeran Beach Hotel Padang dengan menggunakan metode menu engineering. Adapun hasil analisis disajikan pada Tabel 9.

Tabel 9. Menu Engineering Worksheet Menu A'la Carte kategori Selection Juice

\begin{tabular}{|c|c|c|c|c|c|c|c|c|c|}
\hline A & B & C & D & $\mathbf{E}$ & $\mathbf{F}$ & G & $\mathbf{H}$ & $\mathbf{L}$ & $\mathbf{P}$ \\
\hline $\begin{array}{l}\text { Nama } \\
\text { Item }\end{array}$ & $\begin{array}{l}\text { Numb } \\
\text { er } \\
\text { Sold }\end{array}$ & $\begin{array}{c}\text { Men } \\
\text { u } \\
\text { Mix } \\
\%\end{array}$ & $\begin{array}{l}\text { Item } \\
\text { Food } \\
\text { Cost }\end{array}$ & $\begin{array}{l}\text { Item } \\
\text { Sell } \\
\text { Price }\end{array}$ & $\begin{array}{c}\text { Item } \\
\text { C.M } \\
\text { (E-D) }\end{array}$ & $\begin{array}{l}\text { Total } \\
\text { Cost } \\
\left(D^{*} B\right)\end{array}$ & $\begin{array}{c}\text { Total } \\
\text { Revenue } \\
\left(\mathrm{E}^{*} \mathrm{~B}\right)\end{array}$ & $\begin{array}{c}\text { Total } \\
\text { Profit (H- } \\
\text { G) }\end{array}$ & $\begin{array}{c}\text { Profit } \\
\text { (C.M) } \\
\text { Catego } \\
\text { ry }\end{array}$ \\
\hline $\begin{array}{c}\text { Fresh } \\
\text { Papaya } \\
\text { Juice } \\
\text { Fresh }\end{array}$ & 5 & $1 \%$ & $\begin{array}{c}\text { Rp3.4 } \\
66\end{array}$ & $\begin{array}{c}\text { Rp30.0 } \\
00\end{array}$ & $\begin{array}{c}\text { Rp26.5 } \\
34\end{array}$ & Rp17.330 & Rp150.000 & Rp132.670 & Low \\
\hline $\begin{array}{l}\text { Water } \\
\text { Melon } \\
\text { Juice } \\
\text { Fresh }\end{array}$ & 69 & $9 \%$ & $\begin{array}{c}\text { Rp4.5 } \\
14\end{array}$ & $\begin{array}{c}\text { Rp30.0 } \\
00\end{array}$ & $\begin{array}{c}\text { Rp25.4 } \\
86\end{array}$ & $\begin{array}{c}\text { Rp311.46 } \\
6\end{array}$ & $\begin{array}{c}\mathrm{Rp} 2.070 .0 \\
00\end{array}$ & $\begin{array}{c}\text { Rp1.758.5 } \\
34\end{array}$ & Low \\
\hline $\begin{array}{l}\text { Apple } \\
\text { Juice } \\
\text { Fresh }\end{array}$ & 47 & $6 \%$ & $\begin{array}{c}\text { Rp8.5 } \\
84\end{array}$ & $\begin{array}{c}\text { Rp35.0 } \\
00\end{array}$ & $\begin{array}{c}\text { Rp26.4 } \\
16\end{array}$ & $\begin{array}{c}\text { Rp403.44 } \\
8\end{array}$ & $\begin{array}{c}\text { Rp1.645.0 } \\
00\end{array}$ & $\begin{array}{c}\text { Rp1.241.5 } \\
52\end{array}$ & Low \\
\hline $\begin{array}{l}\text { Orange } \\
\text { Juice }\end{array}$ & 357 & $44 \%$ & $\begin{array}{c}\text { Rp7.4 } \\
18\end{array}$ & $\begin{array}{c}\text { Rp35.0 } \\
00\end{array}$ & $\begin{array}{c}\text { Rp27.5 } \\
82\end{array}$ & $\begin{array}{c}\text { Rp2.648. } \\
226\end{array}$ & $\begin{array}{c}\text { Rp12.495. } \\
000\end{array}$ & $\begin{array}{c}\text { Rp9.846.7 } \\
74\end{array}$ & High \\
\hline
\end{tabular}




\begin{tabular}{|c|c|c|c|c|c|c|c|c|c|}
\hline A & B & C & D & $\mathbf{E}$ & $F$ & G & H & $\mathbf{L}$ & $\mathbf{P}$ \\
\hline $\begin{array}{c}\text { Fresh } \\
\text { Avocado } \\
\text { Juice }\end{array}$ & 90 & $11 \%$ & $\begin{array}{l}\text { Rp4.8 } \\
15\end{array}$ & $\begin{array}{c}\text { Rp30.0 } \\
00\end{array}$ & $\begin{array}{c}\text { Rp25.1 } \\
85\end{array}$ & $\begin{array}{c}\mathrm{Rp} 433.35 \\
0\end{array}$ & $\begin{array}{c}\mathrm{Rp} 2.700 .0 \\
00\end{array}$ & $\begin{array}{c}\text { Rp2.266.6 } \\
50\end{array}$ & Low \\
\hline $\begin{array}{l}\text { Terong } \\
\text { Pirus } \\
\text { Juice }\end{array}$ & 7 & $1 \%$ & $\begin{array}{l}\text { Rp4.0 } \\
85\end{array}$ & $\begin{array}{c}\text { Rp30.0 } \\
00\end{array}$ & $\begin{array}{c}\text { Rp25.9 } \\
15\end{array}$ & Rp28.595 & Rp210.000 & Rp181.405 & Low \\
\hline $\begin{array}{l}\text { Pineapp } \\
\text { le Juice }\end{array}$ & 14 & $2 \%$ & $\begin{array}{l}\text { Rp3.8 } \\
54\end{array}$ & $\begin{array}{c}\text { Rp30.0 } \\
00\end{array}$ & $\begin{array}{c}\text { Rp26.1 } \\
46\end{array}$ & Rp53.956 & Rp420.000 & Rp366.044 & Low \\
\hline $\begin{array}{l}\text { Soursop } \\
\text { Juice }\end{array}$ & 17 & $2 \%$ & $\begin{array}{l}\text { Rp3.0 } \\
29\end{array}$ & $\begin{array}{c}\text { Rp30.0 } \\
00\end{array}$ & $\begin{array}{c}\text { Rp26.9 } \\
71\end{array}$ & Rp51.493 & Rp510.000 & Rp458.507 & Low \\
\hline $\begin{array}{c}\text { Dragon } \\
\text { Fruit } \\
\text { Juice } \\
\text { Palm }\end{array}$ & 58 & $7 \%$ & $\begin{array}{l}\text { Rp4.4 } \\
59\end{array}$ & $\begin{array}{c}\text { Rp30.0 } \\
00\end{array}$ & $\begin{array}{c}\text { Rp25.5 } \\
41\end{array}$ & $\begin{array}{c}\mathrm{Rp} 258.62 \\
2\end{array}$ & $\begin{array}{c}\text { Rp1.740.0 } \\
00\end{array}$ & $\begin{array}{c}\mathrm{Rp} 1.481 .3 \\
78\end{array}$ & Low \\
\hline $\begin{array}{l}\text { Young } \\
\text { Juice } \\
\text { Fresh }\end{array}$ & 29 & $4 \%$ & $\begin{array}{c}\text { Rp5.6 } \\
51\end{array}$ & $\begin{array}{c}\text { Rp30.0 } \\
00\end{array}$ & $\begin{array}{c}\text { Rp24.3 } \\
49\end{array}$ & $\begin{array}{c}\text { Rp163.87 } \\
9\end{array}$ & Rp870.000 & Rp706.121 & Low \\
\hline $\begin{array}{l}\text { Mango } \\
\text { Juice }\end{array}$ & 111 & $14 \%$ & $\begin{array}{c}\text { Rp5.2 } \\
84\end{array}$ & $\begin{array}{c}\text { Rp35.5 } \\
00\end{array}$ & $\begin{array}{c}\text { Rp30.2 } \\
16\end{array}$ & $\begin{array}{c}\text { Rp586.52 } \\
4\end{array}$ & $\begin{array}{c}\text { Rp3.940.5 } \\
00\end{array}$ & $\begin{array}{c}\mathrm{Rp} 3.353 .9 \\
76\end{array}$ & High \\
\hline $\begin{array}{l}\text { Total } \\
(\mathrm{N}) \\
\text { Total }\end{array}$ & 804 & $\begin{array}{c}100 \\
\%\end{array}$ & & & & I & $\mathrm{J}$ & M & \\
\hline $\begin{array}{l}\text { Menu } \\
\text { Mix } \\
\mathrm{K}=\mathrm{I} / \mathrm{I}\end{array}$ & 11 & & & & & $\begin{array}{c}\text { Rp4.956. } \\
889\end{array}$ & $\begin{array}{c}\text { Rp26.750. } \\
500\end{array}$ & $\begin{array}{c}\text { Rp21.793. } \\
611\end{array}$ & \\
\hline $\begin{array}{c}\text { (Food } \\
\text { Cost \%) } \\
0=\mathrm{M} / \mathrm{N}\end{array}$ & $19 \%$ & & & & & & & & \\
\hline $\begin{array}{l}\text { (Averag } \\
\text { e Item } \\
\text { Profit) }\end{array}$ & Rp27 & & & & & & & & \\
\hline $\begin{array}{l}\text { Percent } \\
\text { age } \\
\text { Menu } \\
\text { Mix }\end{array}$ & $6 \%$ & & & & & & & & \\
\hline
\end{tabular}

Berdasarkan tabel 9 diatas dapat dilihat bahwa dari 23 menu di kategori Juice Selection Yang memiliki profitabilitas tinggi adalah Fresh Orange Juice dan Fresh Mango Juice.

\section{Pembahasan}

Mentawai Restaurant merupakan bagian yang tergabung dalam Food and Beverage Department di Pangeran Beach Hotel Padang. Mentawai Restaurant merupakan restoran hotel yang menyediakan jasa penjualan makanan dan minuman untuk para tamu yang menginap di hotel dan juga bagi tamu dari luar yang tidak menginap di hotel. Mentawai Restaurant berada di dekat swimming pool area dan memiliki konsep indoor dan outdoor. Restoran ini menyediakan hidangan $A^{\prime} L a$ Carte dan Buffet. Mentawai restaurant memiliki menu A'la Carte dengan 9 kategori yang menarik yang ditawarkan kepada tamu yang menginap di Pangeran Beach Hotel Padang. Menu yang ditawarkan mulai dari menu dengan kategori Any Kind of Soup, Sandwiches, Snack, Pasta and Pizza, Salad, Western Favorites, Burger, Asian Dishes, dan Juice Selection. Menu menjadi salah satu bagian dari keseluruhan penampilan restoran, selain itu menu juga memiliki nilai sebagai alat untuk membantu menjual seluruh makanan dan minuman yang disediakan oleh restoran.

Peningkatan penjualan melalui menu merupakan suatu bentuk profitabilitas. Profitabilitas pada dasarnya merupakan suatu bentuk kemampuan perusahaan untuk mendapatkan keuntungan dengan memanfaatkan sumber daya yang dimiliki perusahaan seperti aktiva, modal atau penjualan perusahaan (Bhawa \& Dewi S., 2015; Rahmah \& Komariah, 2016). Tingkat profitabilitas dilakukan untuk mengukur tingkat efektivitas pengelolaan terhadap penjualan menu-menu yang ditawarkan (Suherman et al., 2019). Perhitungan profitabilitas ini dilakukan dengan metode menu engineering. Menu engineering diartikan 
sebagai serangkaian proses yang dilakukan manajemen dalam evaluasi untuk penyusunan harga, desain dan isi menu pada saat sekarang maupun yang akan datang. Hanya saja kenyataan dilapangan menunjukkan bahwa terdapat beberapa permasalahan yang ditemui pada bagian kitchen. Permasalahan yang ditemui terkait dengan menu yaitu, terdapatnya beberapa menu a'la carte di Mentawai restaurant yang memiliki profit tinggi tetapi kurang diminati konsumen. Terdapat juga menu-menu yang kurang populer tetapi memiliki banyak stock persedian. Cost pada menu-menu yang kurang populer juga tinggi seperti seperti buntut, seafood, dan beef. Adanya pandemic covid-19 kemudian berdampak pada tingkat profitabilitas menu a'la carte yang ada menjadi tidak stabil karena penurunan jumlah penjualan.

Beberapa penelitian yang telah dilakukan sebelumnya mengungkapkan bahwa menu ala carte memiliki empat klasifikasi yakni scilicet 8 Star, 5 Ploughhorse, 4 Puzzle, dan 2 Dog, sehingga data kinerja yang lebih rinci telah disediakan mengenai item menu yang berarti bahwa hasil analisis dapat disajikan baik untuk tujuan bisnis jangka pendek maupun jangka Panjang (Juliana et al., 2021). Hasil penelitian selanjutnya juga mengungkapkan bahwa menu parsial dan penjualan sugestif berpengaruh signifikan terhadap keputusan pembelian, sehingga perusahaan harus mengevaluasi dan meningkatkan kedua variabel ke dalam perencanaan perusahaan untuk meningkatkan keputusan pembelian pada menu a'la carte di Grand Pasundan Convention Hotel (Oktaviani et al., 2018). Penelitian lainnya juga mengungkapkan bahwa teknik rekayasa menu atau menu engineering terbukti berhasil memberikan data identifikasi performa setiap menu yang disajikan dari berbagai aspek mulai dari tingkat popularitas menu makanan di mata konsumen sampai tingkat kontribusi keuntungan yang diberikan oleh setiap menu yang ada (Tumpuan, 2021). Berdasarkan penelitian yang telah dilakukan di Mentawai Restaurant Pangeran Beach Hotel Padang, dapat dijelaskan bahwa dari 73 menu A'la Carte pada bulan Oktober- Desember 2020 dan Januari - Maret 2021 terdapat beberapa menu yang memiliki tingkat profit tinggi, akan tetapi diantara menu-menu yang memiliki profit tinggi tersebut kurang diminati konsumen. Hal ini harus dilakukan promosi agar menu-menu yang memiliki profit tinggi diminati konsumen dan meningkatkan jumlah penjual di Mentawai restaurant. Berdasarkan hasil pembahasan pada penelitian ini maka hal yang harus dilakukan oleh pihak hotel agar penjualan makanan dan minuman meningkat adalah melakukan strategi promosi untuk menarik minat konsumen terhadap makanan dan minuman yang memiliki tingkat profitabilitas tinggi.

\section{SIMPULAN}

Berdasarkan hasil penelitian dan pemaparan mengenai metode menu engineering yang dilakukan pada menu A'la Carte Mentawai Restaurant Pangeran Beach Hotel Padang pada bulan Oktober- Desember 2020 dan Januari - Maret 2021 dapat disimpulkan bahwa hasil analisis menu engineering menunjukan dari 73 menu A'la Carte di Mentawai Restaurant Pangeran Beach Hotel Padang yang memiliki profitabilitas tinggi sebanyak 25 menu.

\section{DAFTAR PUSTAKA}

Besra, E. (2015). Potensi wisata kuliner dalam mendukung pariwisata di kota Padang. Jurnal Riset Akuntansi Dan Bisnis, 12(1). http://journal.umsu.ac.id/index.php/akuntan/article/view/402.

Bhawa, I. B. M. D., \& Dewi S., M. R. (2015). Pengaruh Ukuran Perusahaan, Likuiditas, Profitabilitas, Dan Risiko Bisnis Terhadap Struktur Modal Perusahaan Farmasi. E-Jurnal Manajemen Universitas Udayana, $4(7)$,

255265. https://repositori.unud.ac.id/protected/storage/upload/repositori/0f6815d5cc652c7c42a069ab 4aec2529.pdf.

Dewilda, Y., Aziz, R., \& Fauzi, M. (2019). Kajian Potensi Daur Ulang Sampah Makanan Restoran di Kota Padang. Jurnal Serambi Engineering, http://www.ojs.serambimekkah.ac.id/jse/article/view/1325.

Djausal, G. P., Larasati, A., \& Muflihah, L. (2020). Strategi pariwisata ekologis dalam tantangan masa pandemik COVID-19. Jurnal Perspektif Bisnis, 3(1), 57-61. https://doi.org/10.23960/jpb.v3i1.15.

Ferdiansyah, H., Suganda, D., Novianti, E., \& Khadijah, U. L. (2020). Pengelolaan Mitigasi Krisis Pariwisata Akibat Pandemi Covid-19 Dalam Menghadapi Fase New Normal (Studi Kasus Di Desa Wisata Nglanggeran Yogyakarta). Media Bina Ilmiah, 15(3), 4133-4144. https://doi.org/10.33758/mbi.v15i3.729.

Hesna, Y., Suraji, A., Istijono, B., Hidayat, B., \& Ophyandri, T. (2017). Kajian Kapasitas Infrastruktur: Suatu Upaya Peningkatan Pariwisata Sumatera Barat. IPTEK Journal of Proceedings Series, 3(5). http://iptek.its.ac.id/index.php/jps/article/view/3178.

Juliana, Pramezwary, A., Nukak, N. A., \& Situmorang, J. M. H. (2021). Using Contribution of Menu Engineering 
in Upscale Restaurants to Enhance Sales Volume. International Journal of Social and Management Studies (IJOSMAS), 02(04), 1-12. https: //doi.org/10.5555/ijosmas.v2i4.45.

Kanom, K., Nurhalimah, N., \& Darmawan, R. N. (2020). Recovery Pariwisata Banyuwangi Pasca Covid 19. Media Bina Ilmiah, 15(3), 4257-4266. https://doi.org/10.33758/mbi.v15i3.864.

Masful, M. F. (2017). Pariwisata syariah: suatu konsep kepercayaan dan nilai budaya lokal di daerah pedalaman Pilubang, Payakumbuh, Sumatera Barat. Jurnal The Messenger, 9(1), 1-8. https://journals.usm.ac.id/index.php/the-messenger/article/view/433.

Nasution, D. A. D., Erlina, E., \& Muda, I. (2020). Dampak Pandemi COVID-19 terhadap Perekonomian Indonesia. Jurnal Benefita, 5(2), 212. https://doi.org/10.22216/jbe.v5i2.5313.

Oktaviani, S., Sudono, A., \& Sukirman, O. (2018). Analisis Menu Engineering Pada Menu A'la Carte di Grand Pasundan Convention Hotel Dalam Upaya Meningkatkan Keputusan Pembelian Melalui Suggestive Selling. The Journal Gastronomy Tourism, 5(1), 42-52. https://doi.org/10.17509/gastur.v5i1.22227.

Paramita, I. B. G., \& Putra, I. G. G. P. A. (2020). New normal bagi pariwisata bali di masa pandemi covid 19. Pariwisata Budaya: Jurnal Ilmiah Agama Dan Budaya, 5(2), 57-65. https://doi.org/10.25078/pba.v5i2.1723.

Rahmah, M., \& Komariah, E. (2016). Analisis Laporan Keuangan dalam Menilai Kinerja Keuangan Industri Semen yang Terdaftar di BEI (Studi Kasus PT Indocement Tunggal Prakarsa TBK). Jurnal Online Insan Akuntan, 1(1), 234490. http://ejournal-binainsani.ac.id/index.php/JOIA/article/view/3.

Suherman, Purnamasari, R., \& Mardiyati, U. (2019). Pengaruh Struktur Aset, Likuiditas, dan Profitabilitas terhadap Struktur Modal yang Dimoderasi Oleh Ukuran Perusahaan. Mix: Jurnal Ilmiah Manajemen, 9(2), 369-381. https://doi.org/10.22441/mix.2019.v9i2.009.

Tumpuan, A. (2021). Penerapan Sistem Menu Engineering Dalam Upaya Peningkatan Kualitas Menu di Restoran Bintan Inti Executive Village Clubhouse. Jurnal Pariwisata Terapan, 5(1), 60. https://doi.org/10.22146/jpt.66724.

Utami, B. A., \& Kafabih, A. (2021). Sektor pariwisata Indonesia di tengah pandemi COVID 19. Jurnal Dinamika Ekonomi Pembangunan, 4(1), 383-389. https://doi.org/10.33005/jdep.v4i1.198. 